but whose whole training fits them admirably to fulfil just that purpose which the Commissioners have in mind.

\section{Volcanic Eruptions in the Andes}

Alarming reports of vast showers of volcanic ash from eruptions of Descabezado and other recent volcanoes of the group which oceurs on the chain of the Andes south of Santiago de Chile, appeared in Tuesday's daily papers. The exuptions began on April 10, and the neighbouring towns of San Fernando, Curico, and Talca were said to be in darkness through the fall of fine dust from the volcanoes. The ash is reported to be three feet deep in Curico. Trains arriving at Mendoza, on the line about a hundred miles east of Santiago, were covered with volcanic dust, and the streets of the city were thickly coated with it. At Buenos Ayres, which is about six hundred miles farther east, there has been a steady fall of volcanic ash, and even at Monte Video (Uruguay), still farther east, the shower of dust is reported to have lasted for ten hours. Shocks have been felt over a wide area, but at the time of going to press no details are available as to the actual character of the eruptions or exactly what volcanic peaks have again come into activity.

\section{Overlapping of Government Research Funds}

IT has been common knowledge, amongst those conversant with such matters, that a certain amount of overlapping has existed in connexion with the grants made by Government to various bodies who utilise the money for assisting research and other work in the British Empire. The system underlying these grants has developed by instalments and does not, therefore, represent a carefully thought-out scheme. For this reason the first report of the Estimates Committee, of which Sir Vivian Henderson is chairman, recently presented to the House of Commons, will be welcorned. It is understood that the Committee has examined the estimates of the following funds: Empire Marketing Board, Colonial Development Fund, Development Fund, Ministry of Agriculture, Colonial and Middle Eastern Services, and University Grants Committee. The Estimates Committee's object was to ascertain to what extent in recent years Parliament has been asked for funds to assist the same object or body through different channels, since the Parliamentary estimates do not themselves indicate clearly the sourees of the demand. The Committee has noted, for example, that grants are being allotted to the Empire Marketing Board for many purposes which are also assisted by the Development Fund, the Forestry Commission, the Ministry of Agriculture, or the Department of Scientific and Industrial Research. Again, in the case of the Colonies, grants are being made from the Colonial Development Fund for the ordinary purposes of Government, whilst at the same time, the Colony concerned may be receiving a grant from the Colonial Office. It is not suggested that the departments or bodies receiving such grants are in ignorance of what is being done by others working on the same lines, but the fact remains, as the Committee remarks, that many institutions in Great Britain are receiving assistance from the State through two or three, or even as many as four or five, or more, channels. This position of itself justifies the appointment of the Estimates Committee, the work of which should also prove of service to Government at the Ottawa Conference.

\section{Race Prejudice and World Peace}

Sir Arthur Kaith in his address, "Can Race Progress be Rationalised ?", delivered on April 5 at Oxford, before the Universities Congress of the National Union of Students, turned once more to the problem of world peace as it presents itself to him as an anthropologist and a follower of Darwin. As he has expressed himself on more than one previous occasion, Sir Arthur is convinced that racial and national instinct is an all-powerful factor in the evolutionary progress of mankind, producing new and, perhaps, better races; but, as he points out, this spirit is incompatible with man's economic needs, and the result is the disharmony which is to be seen in the world to-day. Granting that this spirit is ineradicable, and accepting the inevitable consequence that the nations of the world can never be welded into a whole, is it then possible, Sir Arthur asks, to bring about conditions in which each nationality may work out its destiny by peaceful progress? Ethically the nations of to-day are in no respect superior to their predecessors; each pursues its own ends selfishly. Nothing daunted, Sir Arthur sees hope for the future in such manifestations as the suppression of separatist tendencies by reason in Scotland and Wales, and in the spread of English-speaking peoples, which he regards as the greatest attempt to rationalise the peoples of the world that has ever been made. Race progress, he concludes, can be rationalised only by a process of self-understanding, self-education, and, if need be, self-sacrifice on the part of all.

\section{Roman Mining in Britain}

IN a paper on Roman mining in Britain, read before the Newcomen Society on March 30, Mr. G. C. Whittick gave a review of the mining operations during the whole of the Roman occupation. Though the Roman invasion cannot be ascribed chiefly to the desire to gain possession of the country's mineral wealth, after the initial seizure of the south-east of the island, there followed the inevitable accompaniment of the exploitation of minerals, particularly lead. After referring to the mining methods, to the treatment of ores, and to the question of organisation, Mr. Whittick dealt with the mining of coal, gold, copper, lead, iron, and tin. During the first century and a half of the Roman occupation, lead was the most important product of Britain. Lead mining in the Mendips was apparently begun so early as A.D. 49, and production rose rapidly during the reigns of Nero (A.D. 54-68) and Vespasian (A.D. 69-79). The centre of Roman activity in the district was in the valley of the Blackmoor, just south of Blackdown. The ore was obtained from surface workings, and from the waste heaps of the workings many pigs of Roman lead have been recovered. Lead was also 